\title{
Growth of Six Begonia Species Under Shading
}

\author{
Ka Yeon Jeong ${ }^{1}$, Claudio C. Pasian ${ }^{1, *}$, Margaret McMahon ${ }^{1}$ and David Tay ${ }^{2}$ \\ ${ }^{1}$ Department of Horticulture and Crop Science, The Ohio State University, Columbus, Ohio 43210-1086, USA and \\ ${ }^{2}$ Ornamental Plant Germplasm Center, The Ohio State University, 670 Vernon Tharp Street, Columbus, Ohio 43210 \\ USA
}

\begin{abstract}
The Ornamental Plant Germplasm Center (OPGC) conserves begonia species. Limited cultural information is available concerning the effect of light intensity on the growth of begonia species other than cultivated hybrids in greenhouses. The objective of this study was to evaluate the response of begonia species to different shade levels and to identify light intensities that favor the production and maintenance of quality begonia plants in greenhouses during summer. Plants of six begonia species; [Begonia albopicta, B. cucullata var. cucullata, B. echinosepala var. elongatifolia, B. holtonis, B. foliosa var. miniata, and B. 'Fuchsifoliosa' (B. fuchsioides $\mathrm{x}$ B. foliosa)], were grown in a greenhouse in Columbus, $\mathrm{OH}$ (lat. $40 \mathrm{~N}$, long. $82.53 \mathrm{~W}$ ) for 12 weeks (starting $23 \mathrm{July}$ ) either in full light $\left(1000-1800 \mu \mathrm{mol} \cdot \mathrm{m}^{-2} \cdot \mathrm{s}^{-1}\right)$ or shade-cloth tents providing three levels of shade (41, 62, and $76 \%$ of full sunlight in the greenhouse). Each plant was evaluated for the number of inflorescences, leaf greenness (SPAD readings), shoot length, leaf area, and shoot dry weight. Visual observations of plant quality (chlorosis, necrosis, sunburn, deformed leaves, and plant mortality) were also recorded. Shade percentage for optimal growth and quality of B. albopicta, B. echinosepala var. elongatifolia, B. holtonis, B. foliosa var. miniata, and B. 'Fuchsifoliosa' plants was $62 \%$ and $76 \%$ for B. cucullata var. cucullata plants.
\end{abstract}

Key Words: OPGC, ornamental plant germplasm center, light intensity, shade-cloth shelter.

\section{INTRODUCTION}

To conserve the diversity of Begonia and to enhance begonia research and utilization, the Ornamental Plant Germplasm Center (OPGC) located at The Ohio State University (lat. $40^{\circ} \mathrm{N}$, long. $82^{\circ} 53^{\prime} \mathrm{W}$ ) has been collecting and studying Begonia species and hybrids as one of its priority genera since November, 2001. Although this germplasm is a valuable breeding and research resource, few cultural management recommendations, including light, are available. As a result, the plant quality of some begonia species and interspecific hybrids tends to deteriorate due to high light intensity in OPGC greenhouses during summer months.

Irradiance inside greenhouses can increase to levels that not only saturate photosynthesis but also cause heat stress on crops [1]. When photosynthesis does not increase as much as light intensity increases, chloroplasts are injured [2]. Excessive irradiance also causes leaf burn [3-6]. During periods of high solar radiation, use of shading material is recommended to achieve high quality plant production [1]. Low irradiance can also result in poor begonia plant quality by producing weak stems and reduced growth and number of flowers [36]. For example, shoot dry weight, lateral shoot leaf area, total leaf area, and node number of Begonia $\times$ semperflorens-cultorum decreased with increasing shade over time [3].

Shade materials reduce radiation levels in greenhouses [1] and decrease temperature as well [7]. As a result, shade

*Address correspondence to this author at the Department of Horticulture and Crop Science, The Ohio State University, Columbus, Ohio 43210-1086, USA; Tel: 614-292-9941; Fax: 614-292-3505; E-mail: pasian.1 @osu.edu materials in greenhouses are a common commercial practice both to reduce light intensity and greenhouse temperature. Although adequate light is one of the most important environmental requirements for growing high quality begonia plants, there is no information available regarding the optimal light intensity. Determining the optimal shade levels for begonia species would improve conservation techniques at the OPGC and provide useful information to growers requesting the conserved plant material as well as commercial growers.

Begonia albopicta (accession number: OPGC 431), B. cucullata var. cucullata (OPGC 424), B. echinosepala var. elongatifolia (OPGC 426), B. holtonis (OPGC 712), B. fuchsioides var. miniata (OPGC 851), and $B$. 'Fuchsifoliosa' ( $B$. fuchsioides x B. folia) (OPGC 852) were studied due to easy propagation by stem cuttings to produce uniform liners. The OPGC has no information regarding collection locations and their environmental characteristics. Begonia albopicta is a cane-like begonia that originated in Brazil. This species grows well indoors and in gardens [6]. Begonia cucullata var. cucullata is a widespread South American species used as the original parent of most hybrid semperflorens or bedding begonias [6]. Begonia echinosepala var. elongatifolia, $B$. holtonis and B. foliosa var. miniata originated in Brazil, Colombia and Mexico, respectively, and are classified as small, bare-leaf, shrub-like species [6]. Begonia foliosa var. miniata and $B$. 'Fuchsifoliosa' prefer shady locations or those that receive mottled sunlight [6]. All these species have some ornamental potential. The objective of this study was to investigate the effect of different shade levels on the growth and visual quality of five begonia species and one interspecific hybrid. 


\section{MATERIALS AND METHODS}

Tip cuttings with 3 to 5 leaves were harvested from each stock plant and planted in 48-cell pack trays using a soilless substrate consisting of $50 \%$ (by volume) coarse perlite (Horticultural Perlite, Therm-O-Rock East, Inc., New Eagle, PA) and 50\% Metro Mix 360 (Canadian sphagnum peat moss (10 to $20 \%$ ), vermiculite (25 to $40 \%$ ), horticultural grade perlite (5 to $15 \%)$, bark ash (0 to $10 \%)$, pine bark ( 25 to $45 \%$ ) with starter nutrient charge, dolomitic limestone and long-lasting wetting agent (The Scotts Co., Marysville, OH). Cuttings were kept on a mist bench for 40 days for rooting.

Rooted cuttings were transplanted into $11.4 \mathrm{~cm}$ round plastic containers on 23 July 2004 with the soilless substrate, Metro Mix 360. Each container received 7.0 g 16N-3.96P$9.96 \mathrm{~K}$ controlled release fertilizer (Osmocote Plus $16 \mathrm{~N}$ $9 \mathrm{P}_{2} \mathrm{O}_{5}-12 \mathrm{~K}_{2} \mathrm{O}$, the Scotts Co., Marysville, $\mathrm{OH}$ ), applied as a top-dressing. Plants were located inside 6 shade tents built on top of benches inside two glass-glazed-greenhouse compartments $(10 \mathrm{~m} \times 12 \mathrm{~m})$ made of PVC walls inside a $66 \mathrm{~m}$ long glass-glazed greenhouse. Controls consisted of plants grown on top of benches (no shade tent).

Woven shade fabrics of 30,50 , and $80 \%$ shade grade (A.M. Leonard, Piqua, $\mathrm{OH}$ ) were used to build single layered shade-cloth tents $(1.5 \times 2.0 \times 1.5 \mathrm{~m})$. The tents had openings on their east and west sides to allow air circulation. Each greenhouse compartment had good air circulation provided by two fans on the outside (west) wall and air inlets on the east side. Photosynthetic photon flux density (PPFD) inside and outside each shade-cloth tent was measured on four randomly selected days between 12:00 noon and 14:00 hr. using a Quantum Meter (BQM-ELEC, HYDROFARM, Petaluma, CA) (Table 1). Based on the measured light levels, woven shade fabrics of 30,50 , and $80 \%$ shade grade resulted in light reductions of 41,62 , and $76 \%$, respectively (Table $\mathbf{1}$ ). Plants were grown for 12 weeks during the summer. Average day and night temperatures in each greenhouse compartment for the whole growing period were $26.8 \pm 3.9^{\circ} \mathrm{C}$ (mean $\pm \mathrm{SE}$ ) and $19.9 \pm 1.2^{\circ} \mathrm{C}$, respectively. Plants were watered as needed using tap water. Frequency ranged from twice a week at the beginning, to daily at the end of the experiment for plants in full sun. Plants in the shade required less frequent irrigation.

This factorial experiment was arranged in a split-plot design with control (no shade) and three levels of shading as main plots and six begonia species as sub-plots. There were two replications. One replication was located in one greenhouse compartment and the other was located in a second compartment. The four treatments were randomly arranged in each replication. Three plants of each species were randomly placed under each level of shade treatment.

The number of inflorescences (NI) was recorded weekly after the flowers of each inflorescence appeared. At the end of the experiment, leaves at the third node of two to five stems per plant were randomly selected and a SPAD chlorophyll meter (Minolta SPAD502 meter, Spectrum Technologies, Plainfield, IL) was used at 15 to 20 randomly chosen locations in the selected leaves to determine relative leaf greenness. Shoot length (SL), total leaf area (LA), and shoot dry weight (DW) of all plants were also measured. Shoot length was defined as the length from the surface of the substrate to the tip of the longest shoot of each plant. Total leaf area was measured using a LICOR 3100 leaf area meter (LICOR, Lincoln, NE). All above ground plant parts for DW measurement were harvested and dried in a forced air oven at 55 to $60^{\circ} \mathrm{C}$ for 5 days. In addition, visual observations of leaf chlorosis, necrosis, sunburn, deformed leaves, and plant mortality were recorded throughout the experiment. For the purposes of this study the term "quality" includes 1) plant growth characteristics such as dry weight, stem length, total leaf area; 2) physiological characteristics such as number of inflorescences and SPAD readings and 3) visual observa-

Table 1. Estimated Shade Levels (\%) in two Blocks, Calculated by Measuring Photosynthetic Photon Flux Density (PPFD, $\mu \mathrm{mol} \cdot \mathrm{m}^{-2} \cdot \mathrm{s}^{-1}$ ) Outside and Inside of Each Shade-Cloth Tent at Four Dates. Average Shade Levels Obtained with 30, 50, and $80 \%$ Shade Cloth were 41, 62, and $76 \%$, Respectively

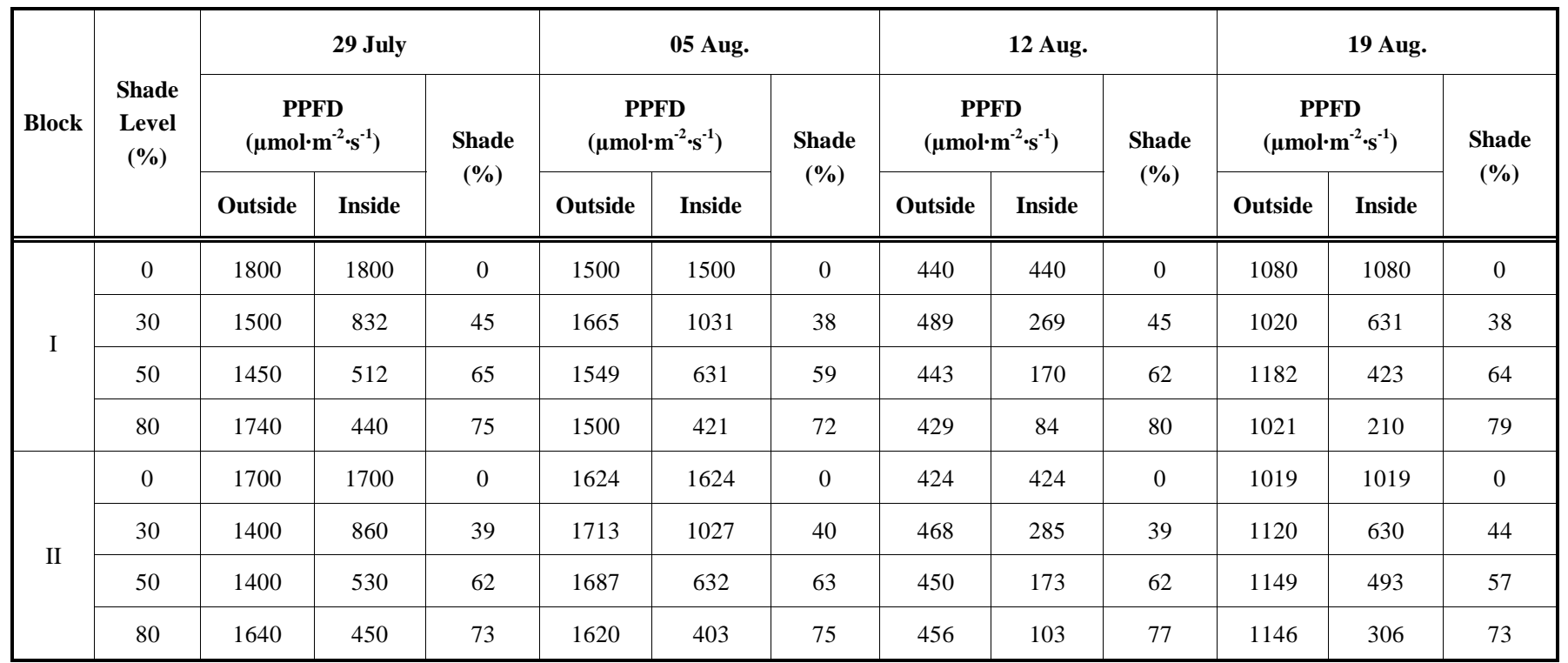


tions of leaf chlorosis, necrosis, sunburn, deformed leaves, and plant mortality.

The collected data were subjected to analysis of variance (ANOVA) in a split-block design using the GLM Procedure of Enterprise Guide 3.0 of the Statistical Analysis Software (SAS Institute, Cary, NC). When the quadratic trend of a growth characteristic with increasing shade level was significant $(P \leq 0.05)$, the fitted curve indicates the predicted values by the linear regression model.

\section{RESULTS AND DISCUSSION}

Depending on species, the responses to different shade levels were different in NI, SPAD, SL, LA and DW (Figs. 1 to 5). The response of most growth characteristics to changes in shade levels had low coefficients of determinations $\left(\mathrm{R}^{2}\right)$ such as in NI of B. echinosepala var. elongatifoliosa $\left(\mathrm{R}^{2}=\right.$
0.24) or B. albopicta $\left(\mathrm{R}^{2}=0.25\right)$ (Fig. 1). In contrast, the response of SPAD and SL as a function of shade levels for B. echinosepala var. elongatifolia (Figs. 2 and 3) and LA for B. cucullata var. cucullata (Fig. 4) had higher coefficients of determination: $0.79,0.86$, and 0.60 , respectively.

According to Kessler and Armitage [3], Begonia $\times$ semperflorens-cultorum plants grown under shade produced smaller and fewer flowers compared to plants in ambient light. Plants of most Begonia species grown under $76 \%$ shade had the smallest NI (Fig. 1). B. echinosepala var. elongatifolia and $B$. 'Fuchsifoliosa' plants produced the largest NI in full sun. However, the largest NI of B. albopicta plants grown under $41 \%$ shade was not in agreement with Kessler and Armitage [3]. They found that Begonia $\times$ semperflorens-cultorum plants grown under shade had smaller and fewer flowers compared to plants in ambient light. Regardless of shade level, B. holtonis had almost no flowers.

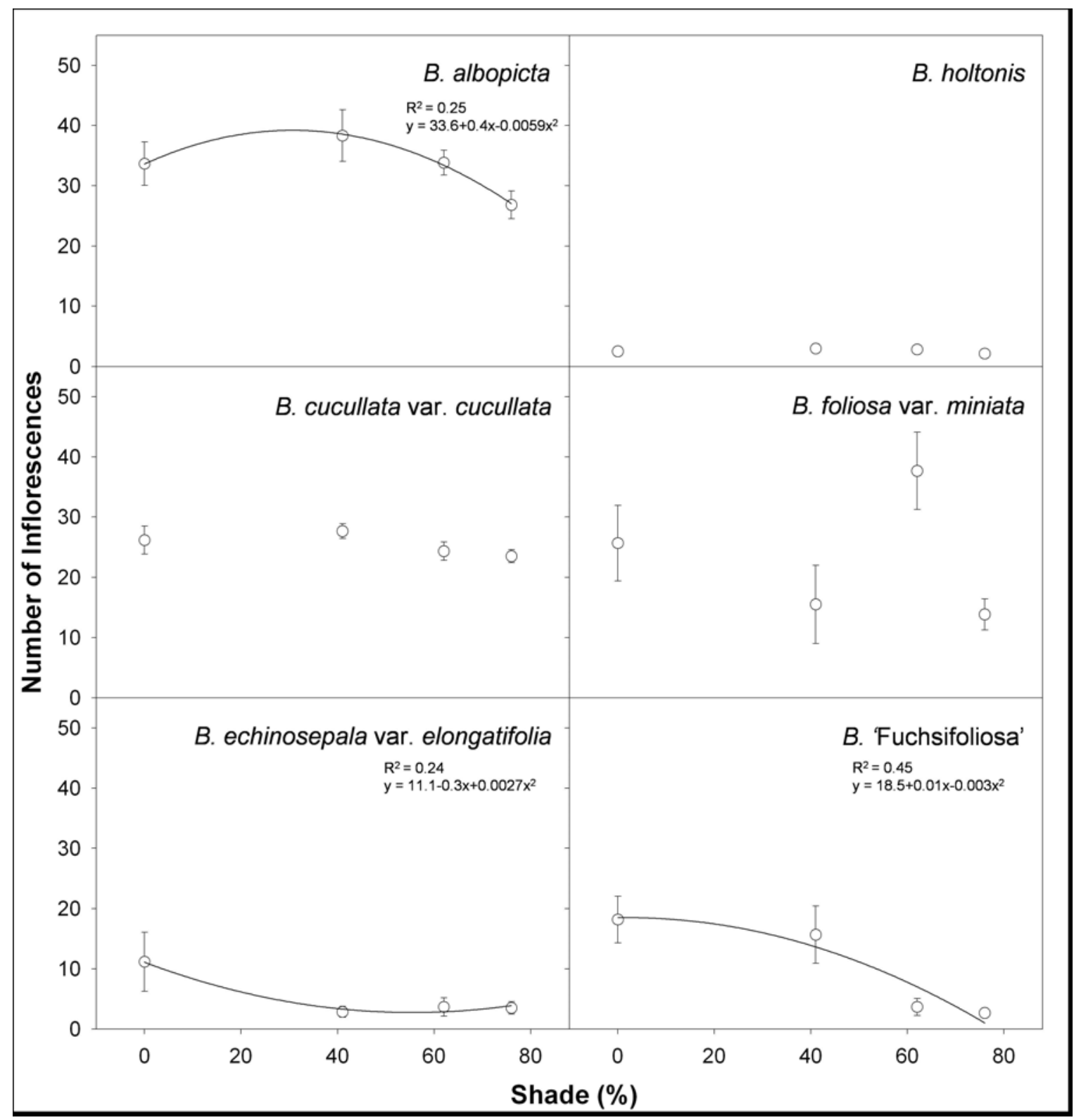

Fig. (1). Number of inflorescences (NI) per plant of six Begonia species (B. albopicta, B. cucullata var. cucullata, B. echinosepala var. elongatifolia, B. holtonis, B. foliosa var. miniata, B. 'Fuchsifoliosa') grown at 0, 41, 62, and 76\% shade levels. Symbols represent the average NI, and solid lines represent the predicted values of a quadratic model when the fitting was significant $(P \leq 0.05)$. Error bars $=$ SE. 


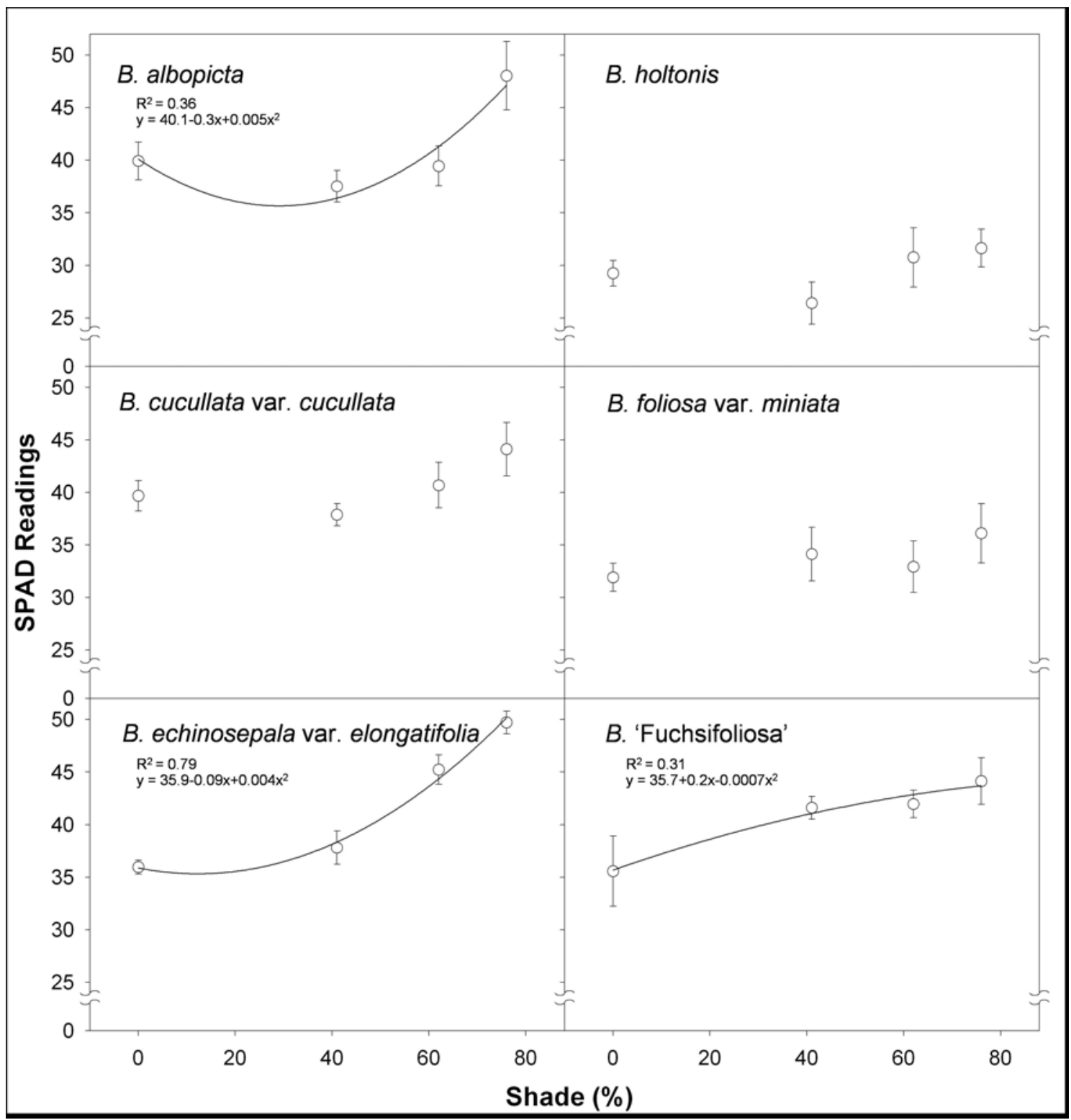

Fig. (2). SPAD readings of six Begonia species (B. albopicta, B. cucullata var. cucullata, B. echinosepala var. elongatifolia, B. holtonis, B. foliosa var. miniata, $B$. 'Fuchsifoliosa') grown at 0, 41, 62, and 76\% shade levels. Symbols represent the average SPAD, and solid lines represent the predicted values of a quadratic model when the fitting was significant $(P \leq 0.05)$. Error bars $=\mathrm{SE}$.

This species may require reaching certain age and size before abundant flowering occurs. B. cucullata var. cucullata, on the other hand, seems to be very plastic when it comes to flowering and shading since it produced the same number of inflorescences regardless of shade level. Similarly, inflorescence production of $B$. foliosa var. miniata, is irresponsive of percent shade. Large differences in the number of inflorescences per plant were noted in this species at each shade level as noted by the large standard error bars of the means (Fig. 1). Shade level to produce maximum NI was dependent on Begonia species (Fig. 1).

The highest SPAD values were consistent with visual observations of more intense green leaves of B. albopicta, $B$. echinosepala var. elongatifolia, and $B$. 'Fuchsifoliosa' plants grown at $76 \%$ shade (Fig. 2). When shade levels were below $76 \%$, the response was species dependent (Fig. 2). The response of Begonia semperflorens-cultorum Hort. to light intensity has been reported by Nemali and van Iersel [8]. They found that as the level of daily light integrals decreased, leaf chlorophyll concentrations (SPAD readings) increased resulting in more efficient light capture for maximum photosynthesis.

SPAD readings were not significantly different among the $B$. albopicta plants grown under 0,41 , and $62 \%$ shade. The leaves of $B$. 'Fuchsioides' plants grown under full sun were chlorotic and had significantly lower SPAD values than plants grown under shade (Fig. 2). B. holtonis, B. cucullata var cucullata, and B. foliosa var miniata plants had similar SPAD readings irrespective of the shade level at which they were grown.

Although B. cucullata var. cucullata plants appeared greener with increasing shade levels, no significant association of SPAD values with increasing shade was found. This finding was due to the fact that leaves on the third node from 


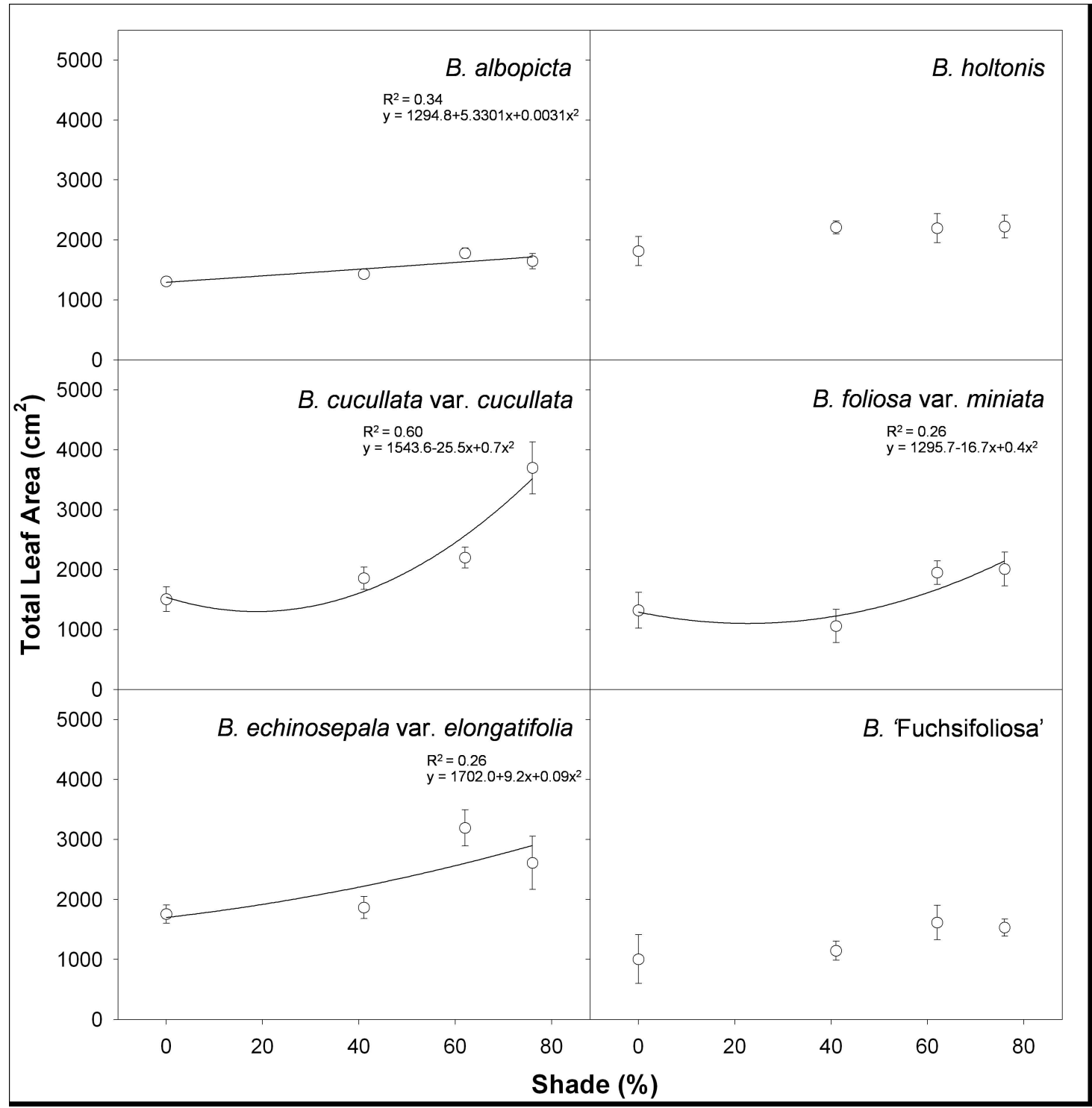

Fig. (4). Total leaf area (LA) per plant of six Begonia species (B. albopicta, B. cucullata var. cucullata, B. echinosepala var. elongatifolia, B. holtonis, B. foliosa var. miniata, B. 'Fuchsifoliosa') grown at 0, 41, 62, and 76\% shade levels. Symbols represent the average LA, and solid lines represent the predicted values of a quadratic model when the fitting was significant $(P \leq 0.05)$. Error bars $=\mathrm{SE}$.

were substantially lower than those measured in our study (Table 1). Based on our results, the Begonia species studied in this work are very plastic in their responses of DW to shade levels because shade level had almost no effect on how much a plant grew. Based on visual observations, shade levels had an effect on plant appearance rather than on plant growth.

Begonia albopicta plants grown in full sun were visibly more stunted and compact than plants grown under shade. Similarly, full sun plants had smaller and upward cupping leaves. Full sun and $41 \%$ shade resulted in reddish, cupping leaves of B. echinosepala var. elongatifolia plants. These symptoms are similar to those reported by Mortensen and Ulsaker [3] who found that leaves of Begonia $\times$ hiemalis Fotsch were chlorotic, curled and reddish at $390 \mu \mathrm{mol} \cdot \mathrm{m}^{-2} \cdot \mathrm{s}^{-1}$. The plant mortality rate was $16.7 \%$ for $B$. foliosa var. miniata and $B$. 'Fuchsifoliosa' plants grown in full sun. All Begonia species studied at $76 \%$ shade had sparse and soft foliage.
Our results confirm that the optimal shading for each species' is different. Thus each begonia species' optimal shading level must be identified to produce high quality begonia plants in a greenhouse during summer. In this study, the optimal shade level for B. albopicta, B. echinosepala var. elongatifolia, B. foliosa var. miniata, and B. 'Fuchsifoliosa' was $62 \%$ and $76 \%$ for B. cucullata var. cucullata. Even though there was no significant effect of shade on the growth characteristics of $B$. holtonis plants, those grown at $62 \%$ shade produced visually appealing plants with no sunburn damage observed at $41 \%$ shade and full sun.

\section{ACKNOWLEDGEMENTS}

Publication of this manuscript was approved by the Department of Horticulture and Crop Science of The Ohio State University. Salaries and research support were provided by state and federal funds appropriated to The Ohio State University, Ohio Agricultural Research and Development Center as well as the Ornamental Plant Germplasm Center. 


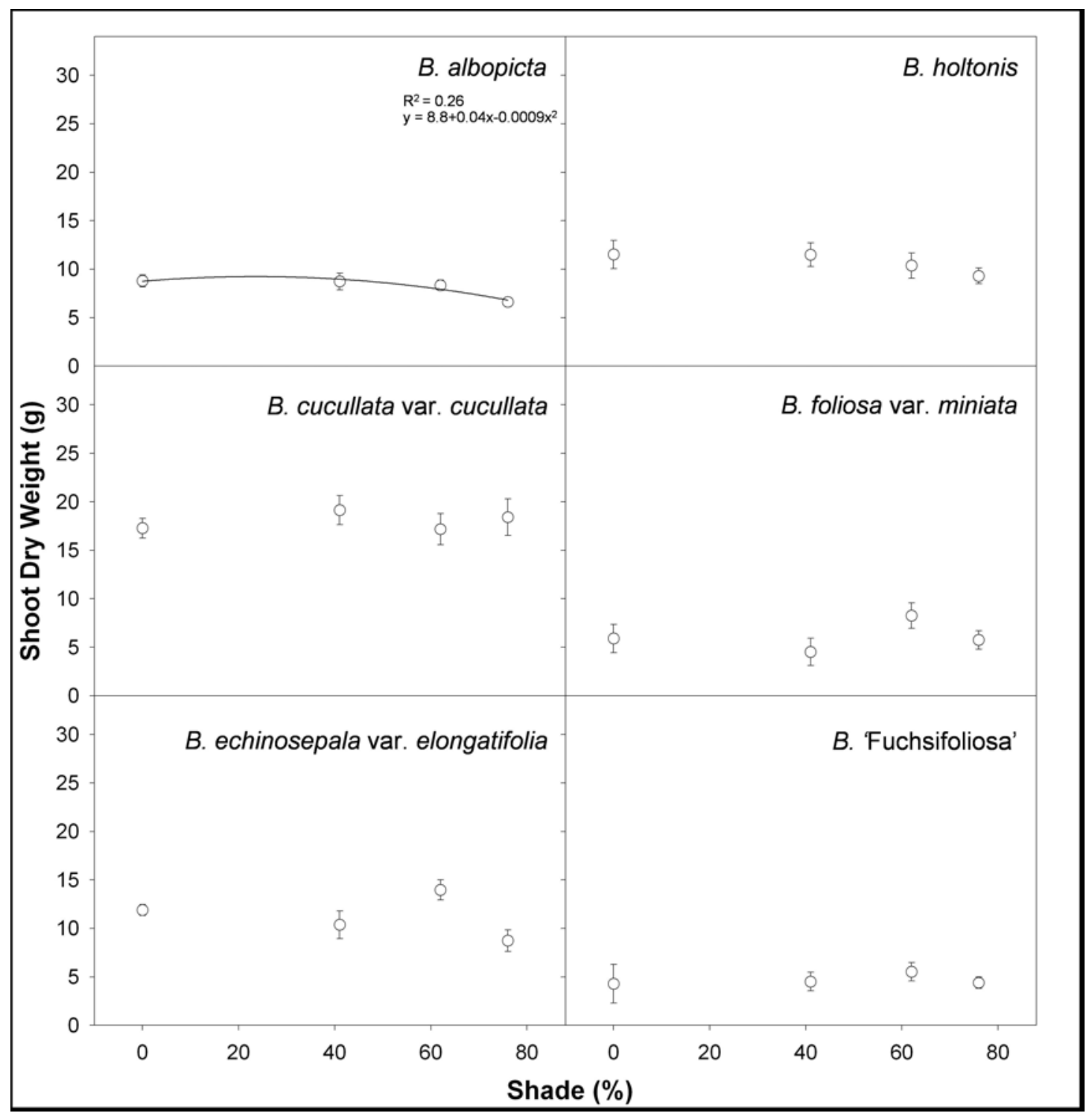

Fig. (4). Total leaf area (LA) per plant of six Begonia species (B. albopicta, B. cucullata var. cucullata, B. echinosepala var. elongatifolia, B. holtonis, B. foliosa var. miniata, B. 'Fuchsifoliosa') grown at $0,41,62$, and $76 \%$ shade levels. Symbols represent the average LA, and solid lines represent the predicted values of a quadratic model when the fitting was significant $(P \leq 0.05)$. Error bars $=\mathrm{SE}$.

were substantially lower than those measured in our study (Table 1). Based on our results, the Begonia species studied in this work are very plastic in their responses of DW to shade levels because shade level had almost no effect on how much a plant grew. Based on visual observations, shade levels had an effect on plant appearance rather than on plant growth.

Begonia albopicta plants grown in full sun were visibly more stunted and compact than plants grown under shade. Similarly, full sun plants had smaller and upward cupping leaves. Full sun and $41 \%$ shade resulted in reddish, cupping leaves of B. echinosepala var. elongatifolia plants. These symptoms are similar to those reported by Mortensen and Ulsaker [3] who found that leaves of Begonia $\times$ hiemalis Fotsch were chlorotic, curled and reddish at $390 \mu \mathrm{mol} \cdot \mathrm{m}^{-2} \cdot \mathrm{s}^{-1}$. The plant mortality rate was $16.7 \%$ for $B$. foliosa var. miniata and $B$. 'Fuchsifoliosa' plants grown in full sun. All Begonia species studied at $76 \%$ shade had sparse and soft foliage.
Our results confirm that the optimal shading for each species' is different. Thus each begonia species' optimal shading level must be identified to produce high quality begonia plants in a greenhouse during summer. In this study, the optimal shade level for B. albopicta, B. echinosepala var. elongatifolia, B. foliosa var. miniata, and B. 'Fuchsifoliosa' was $62 \%$ and $76 \%$ for B. cucullata var. cucullata. Even though there was no significant effect of shade on the growth characteristics of B. holtonis plants, those grown at $62 \%$ shade produced visually appealing plants with no sunburn damage observed at $41 \%$ shade and full sun.

\section{ACKNOWLEDGEMENTS}

Publication of this manuscript was approved by the Department of Horticulture and Crop Science of The Ohio State University. Salaries and research support were provided by state and federal funds appropriated to The Ohio State University, Ohio Agricultural Research and Development Center as well as the Ornamental Plant Germplasm Center. 


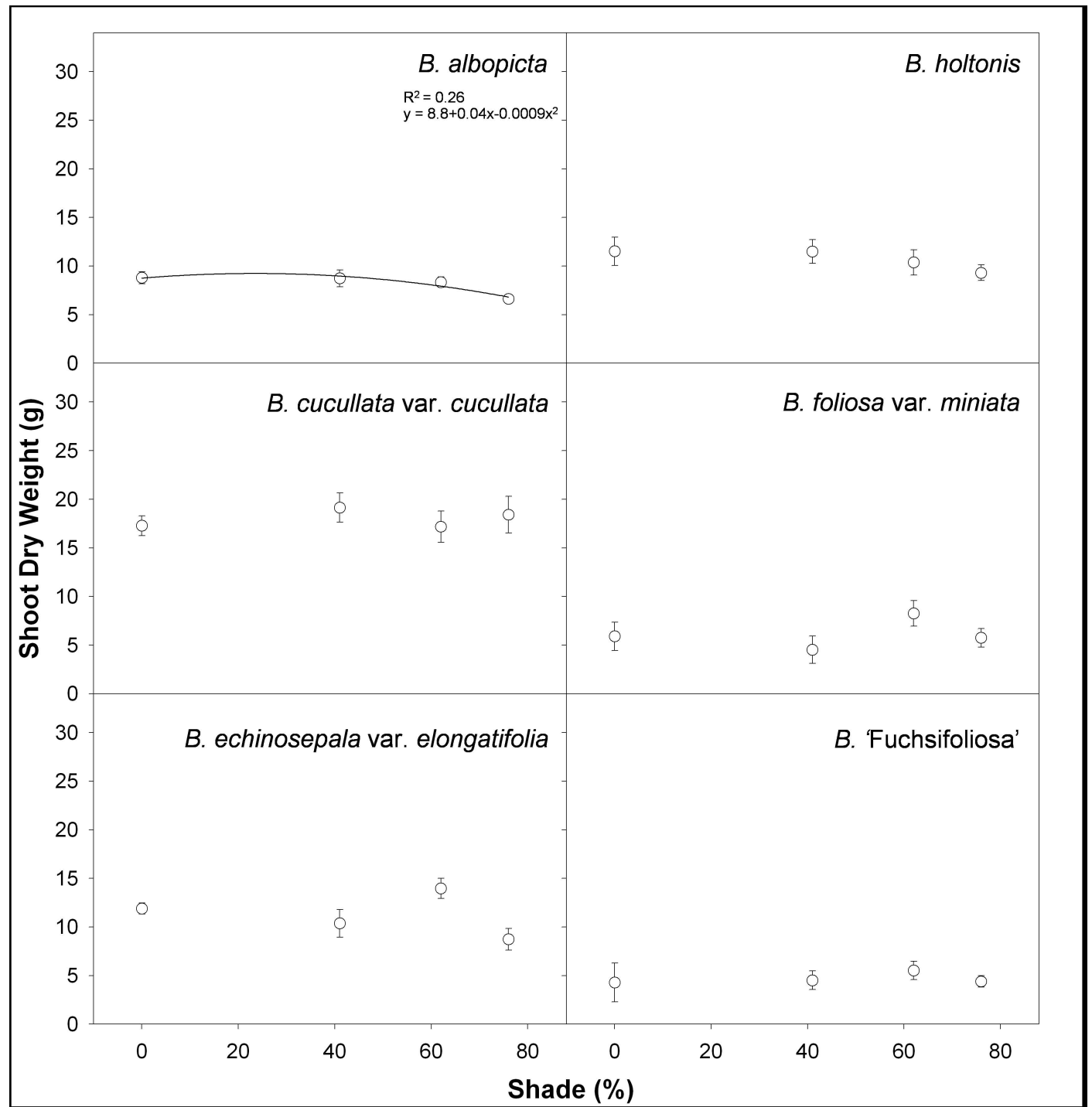

Fig. (5). Shoot dry weight (DW) per plant of six Begonia species (B. albopicta, B. cucullata var. cucullata, B. echinosepala var. elongatifolia, B. holtonis, B. foliosa var. miniata, B. 'Fuchsifoliosa') grown at 0, 41, 62, and 76\% shade levels. Symbols represent the average DW, and solid lines represent the predicted values of a quadratic model (linear regression) when the fitting was significant $(P \leq 0.05)$. Error bars $=\mathrm{SE}$.

\section{REFERENCES}

[1] Al-Arifi A, Short T, Ling P. Influence of shading ratio, air velocity and evapotranspiration on greenhouse crop microclimate. ASAE International Meeting. July 19-21. Toronto, Ontario: Canada 1999.

[2] Nelson PV. Chapter 12. Light and Temperature. In Greenhouse Operation and Management. $6^{\text {th }}$ ed. Prentice Hall. Englewoods Cliffs: USA 2003; p. 400.

[3] Kessler JR, Armitage AM. Effects of shading on growth rate, flower initiation and flower development of Begonia $\times$ semperflorens-cultorum. J Hortic Sci 1992; 67(6): 849-54.

[4] Quigley MF, Mulhall S. Effects of variable shading in a greenhouse study on rhizome weight, root length, and bud proliferation in goldenseal. Hortic Technol 2002; 12(4): 717-20.
[5] Santos MM, Morales-Payan JP, Bewick TA, Shilling DG. Effects of shading on the growth of nutsedges. Weed Sci 1997; 45: 670-3.

[6] Thompson M, Thompson EJ. Begonias: The complete reference. Times Books, New York: NY 1981.

[7] Willits DH. Greenhouse shading. NC Flower Grower's Bull 1992; 1: 8-10.

[8] Nemali KS, van Iersel MW. Acclimation of wax begonia to light intensity: changes in photosynthesis, respiration, and chlorophyll concentration. J Am Soc Hortic Sci 2004; 129(5): 745-51.

[9] Mortensen LM, Ulsaker R. Effect of $\mathrm{CO}_{2}$ concentration and light levels on growth, flowering and photosynthesis of Begonia $\times$ hiemalis Fotsch. Sci Hortic 1985; 27: 133-41. 